\title{
Liberal Arts Faculty as Mediators: the Pulaski County Program
}

\author{
John S. Miller and \\ Cal Ledbetter, Jr.
}

\section{Introduction}

The effectiveness and efficiency of the justice system is a continuing focus of research, and public attention. Burdened by crowded dockets and demands policy for improved conditions and service, the justice system is examining new operative and management alternatives to traditional adjudication such as courtordered arbitration, mediation programs and even private sector initiatives for handling disputes. In this paper we discuss the Pulaski County Mediation Program (MP), an innovative alternative to the traditional courtroom resolution of disputes in small claims, juvenile, and chancery court. The MP brings together, in a joint program, the needs, facilities, support and strengths of Pulaski County and the human and administrative resources of the University of Arkansas at Little Rock (UALR), College of Liberal Arts.

Like County Courts throughout the United States, the Pulaski County Small Claims, Juvenile and Chancery Courts are understaffed and underfunded to meet citizen demand. Based on program evaluation by participants, the mediation program seems to alleviate this urgent public problem in several ways. First, the project facilitates access to the justice system by providing county citizens a free alternative to traditional litigation. Second, the project assists citizens in reaching a mutually acceptable solution to their dispute, thus leading to a more "effective" dispute resolution. Third, the project provides this service in an effective, efficient and personal manner. Fourth, the project has provided a positive first experience with the justice system for many Pulaski County citizens. And fifth, through the use of college faculty as mediators, the project enhances community involvement in the dispute resolution process.

\section{Humanists as Mediators}

Since April 1981 UALR's College of Liberal Arts has provided mediation services to the Pulaski County Small Claims, Juvenile and Chancery Courts. We have recently begun work with the Prosecuting Attorney's Office. Funding for this unique program has come from the Arkansas Endowment for the Humanities, Aetna Life and 
Casualty Foundation, and the Pulaski County Quorum court. The funding pays faculty mediators $\$ 30$ a case and supports one or two student interns at minimum wage.

The idea for the project is based on a program in Maine which is described in the May, 1980 issue of the American Bar Association Journal (Greason, 1980). The Maine program was highly successful with the mediators being able to settle 65 percent of their cases. In fact, the mediator program in Maine has been so valuable that even though it started with grant funds, it is now financed as an integral part of the judicial budget of the State of Maine (McEwen and Maiman, 1984).

With the Maine program serving as a guide, a group of interested faculty and administrators at UALR met with the judges of the Pulaski County Small Claims Court, the Pulaski County Juvenile Court, and the president of the Pulaski County Bar Association to see if a similar project could be developed for Arkansas. A small planning grant $(\$ 500)$ was obtained from the Arkansas Endowment for the Humanties in July 1980 to study the feasibility of the mediation project. A student intern was employed to help with the "nuts and bolts'. The faculty were polled to see who would be interested in becoming mediators (about 30 percent were) and the procedures at both Small Claims and Juvenile Courts were studied to see how faculty members could be integrated into the existing court systems. The study concluded that a mediation program employing UALR professors would be very beneficial to the Small Claims and Juvenile Courts in Pulaski County.

In 1981, a grant was awarded by the Arkansas Endowment for the Humanties for full funding (about $\$ 9,000$ ) of the program. The grant money was to be used primarily to reimburse mediators for their services and to pay student interns. Before any formal mediation began, the participating faculty went through a half day training session at UALR and also observed actual court cases in Small Claims and Juvenile Courts. UALR faculty began handling cases in April of 1981 and the program was officially underway (see Ledbetter, Parins and Flurry, 1982).

The primary assumption of both the Maine and UALR projects is that the liberal arts teaches skills useful for the resolution of disputes. The UALR project began with this assumption and, based on evaluations received, it has proven to be accurate. Humanities and social science professors who have a concern for people and a desire to increase understanding among people, are a natural ally to the courts where litigation often occurs because of failed communication.

Humanities and social science professors who participate in the program have training, experience and an interest in working with people and solving human problems. Attention to the symbolic interaction occurring and the dynamics of the small group within the mediation setting is combined by the mediator with the transferable classroom skills of listening, probing, moderating, summarizing, speaking, explaining, evaluating, and balancing. Mediators also report that familiarity with the social and historical meaning of roles and status such as age, sex, race and ethnicity have aided them in "taking the role" of both plaintiff and defendant. 
The mediator has more time to nurture better interpersonal communication than does a judge, who is often overworked and under pressure to dispose of cases quickly. Furthermore, judges by definition must act according to law, even when the law does not prescribe what might be the best solution. The mediator, on the other hand, can mediate each case on its own merits and needs. When participating in a mediation, the mediator can encourage the two parties to engage in a lively give and take, while in court, communication is between the judge and defendant or plaintiff, never between plaintiff and defendant. In court, defendant and plaintiff are discouraged from speaking unless directed to do so by the judge.

Quantitatively and qualitatively Pulaski County's Mediator Program has had a significant impact on citizens using the county's justice system. In 1984, 78 percent of the 390 cases processed by the program were resolved. In 1985, 81 percent of 377 cases processed were resolved with the assistance of the mediators and student interns. Monetarily, in 1985 nearly $\$ 37,000$ worth of cases were successfully mediated in Pulaski County Small Claims Court. Thus far in 1986 (January thru May) 312 cases out of 365 ( 84 percent) have been successfully resolved. Monetarily this translates into $\$ 35,000$ worth of cases in Small Claims Court.

Qualitatively an enumeration of the evaluation forms filled out by plaintiff and defendant after each mediation session and submitted to court personnel points to the objectivity, sensitivity and effectiveness of the mediators. Eighty percent of those using the mediation services said they believed the mediator was impartial and balanced in his/her approach. Eighty-five percent believed the mediator encouraged them to reach a settlement and 90 percent said they would recommend the mediation program to others. Overall, 75 percent said they were satisfied with the program.

The effectiveness of any program is gauged not only by the outcome it produces (that is, in this instance, cases resolved) but, by how it produces them. In short, those using the MP are quite satisfied with the experience, reflecting positively on the program. The program has also had an impact on participating faculty. Mediators report that involvement in the program has resulted in their being more perceptive and understanding of everyday local government and citizen problems. Likewise citizens report they find it refreshing to work with professors involved in community service.

\section{Existing Mediation}

A project director coordinates the program in the various courts. It is his/her responsibility to assure the integration of the mediation program into the courts, to supervise the training of the interns and mediators, and to help evaluate the program as it progresses and expands. A paid student intern serves each court and chooses cases appropriate for mediation. Appropriate cases are those that fall within the small claims statute and those referred to the project by the various courts. The intern contacts plaintiff, defendant, and mediator, arriving at a mutually agreeable meeting time. Criminal cases, because of their prolonged nature, are handled somewhat 
differently. The judge suspends the criminal charge for six months, referring the case to mediation. The mediator arranges an initial meeting between both parties and airs the dispute. Over the six-month period that ensues, if a problem arises between the disputants, they contact the mediator rather than the court. Meetings are arranged and continuing dialogue occurs. At the end of the six-month period, the mediator sends the court a report. The judge decides final disposition of the criminal case, in large part according to the mediator's recommendation.

\section{Process Example}

While each case is different, the mediation process follows a fairly routine course. Mediation begins with introductions and an explanation of the program by the mediator. The advantages of mediation are explained to plaintiff and defendant, such as no court costs, fewer rules, and compromise as a possible outcome.

The mediator then hears from the plaintiff and the defendant. Discussion might begin with broad diagnostic questions from the mediator such as, "What is your view or interpretation of your disagreement with Mr. Smith?" Synthesis questions can be used as follow-ups such as, "How does this relate to your complaint or your response to Mr. Smith's complaint?"

Next, the mediator applies his or her skills in searching for points of agreement or disagreement, focusing in on the root of the problem. Skills of "taking the role of the other," or placing yourself in anothers "shoes" come into play. The mediator must be able to "see" the problem from the point of view of both plaintiff and defendant. Sensitivity to real or perceived power differentials based on sex, race or age must be exercised.

The mediator must often use the skills of questioning, summarizing, probing and moderating to reach agreement on exactly what the issue is. Questions of clarification as to "Who did what, when and why?" are crucial in making sure everyone is talking about the same things. Questions asking the parties to summarize their position or their view of the situation are useful at this point. The mediator can close this phase of the process by summarizing the two points of view, their agreement or disagreement, in his/her own words as "What I hear you saying is .

During the next phase of mediation the parties are asked to suggest solutions and negotiation of ten ensues. Again the skills enumerated above come into play. Creativity may be called for at this point in the process. Specifically, questions of action and or decision can be raised by the mediator. For example, "What is the most important issue?" or "Which issue or issues should we address?" If that fails, the mediator can take the initiative and suggest, "From what you have told me . . . appears to be the key issue(s). Am I correct?"

Mediation is concluded in one of three ways. First, mediation can fail. If this occurs, the plaintiff has the option of going to court. Second, the case can be successfully mediated. Success means the two parties agree to a solution. Solutions can often be arrived at by encouraging the parties to think hypothetically. "Suppose that Mrs. 
Jones agrees to . . . Would that satisfy you?" If an agreement is made, it becomes the judgement of the court in small claims, while in Juvenile and Criminal court it becomes a recommendation to the judge. Finally, if for some reason more time is needed (such as when additional data is required), the case can be continued and another mediation session scheduled.

\section{Training}

The success of the UALR program is in part based on the training that each mediator undergoes. A mediation handbook has been prepared for each mediator (McNally, 1982). The handbook, authored by a participant in the program, discusses the purpose and philosophy of the program, the role of the mediator, the mediation procedure, and suggests some mediation strategies. Training is conducted yearly in a day-long workshop given by experienced mediators.

We have found that material such as short papers, descriptive case examples and descriptive materials about the justice system as it relates to the program (Merritt, 1984; Miller, 1985) prepared by experienced mediators are much more effective in orienting new mediators than is a reading list of academic articles. Workshop topics include a description of the mediation program, the role of the mediator, small group techniques and the justice system.

Consultants with expertise in mediation/arbitration are often brought in to highlight general mediation strategies and skills. These individuals are drawn from the UALR College of Business, the UALR School of Law, the Federal Mediation Service and outside mediation trainers. Role-playing in a simulated mediation session completes the workshop.

\section{Evaluation}

The project director evaluates the success of the various components of the project on a day-to day basis. It is the director's responsibility to make any changes that are necessary in the workings of the courts, interns, and mediators. The project director is the problem solver, constantly evaluating and fine-tuning the project's administration. The mediators are asked for an evaluation of the program at the close of the budget year.

An advisory panel made up of court personnel and liberal arts faculty meets at least twice a year for a thorough evaluation of the program. The director makes contact frequently with court personnel as individual problems arise. Plaintiff and defendant also complete evaluation forms which are returned to the project director for analysis. Success is measured by the level of satisfaction expressed by the clients of the program and by the percentage of cases resolved.

\section{New Directions}

The successes of the project-and they are considerable-have not led to complacency. To the contrary, these successes have proven the viability of the original idea and encouraged the experimentation and 
expansion of the project. In the future, the group of trained and experienced mediators created by this project will participate in several new areas:

1. At the request of the Pulaski County Judge, mediation will be made available to disputing governmental agencies.

2. Work has begun with the Pulaski County Prosecuting Attorney's Office in establishing a post-conviction mediation program and a preformal complaint mediation/diversion program.

3. The program has also made preleminary central with the Arkansas Department of Human Services to provide mediation services to school districts and parents in cases where they are dissatisfied with the education program prepared for their handicapped children.

\section{References}

Greason, J. (1980) "Humanists as Mediators: An Experiment in the Courts of Maine," American Bar Association Journal, Vol. 66:576.

Ledbetter, Cal, Jim Parins and Melinda Flurry (1982) "Professors as Mediators," Arkansas Lawyer, October: 172-173.

McNally Kathleen A. (1982) Mediation: Little Rock's Alternative to the Courts. Little Rock: University of Arkansas at Little Rock.

McEwen, Craig and Richard J. Maiman. (1984) "Mediation in Small Claims Court: Achieving Compliance Through Consent," Law and Society Review, Vol. $18: 11$.

Merritt, Linda. (1984) Mediation Procedures. Little Rock: University of Arkansas at Little Rock

Miller, John S. (1985) "Sociologists as Mediators: Clinical Sociology in Action," Clinical Sociology Review, Vol. 3:158-164. 